of energy, especially in radiation, with the author's usual ability, and the same may be said of the fifth paper, by the same skilful experimenter, on the deviations of the oscillations of a viscous solid from the isochronous law. Mr. J. P. Dalton gives a careful digest of the accuracy attainable with a modified form of Attwood's machine, whilst Mr. J. B. Ritchie further extends previous researches by Prof. Peddie on the dissipation of energy and other effects observed in torsional oscillation. The last of this series is an account of interesting experiments on wave impact on engineering structures, carried out by Prof. A. H. Gibson and Mr. W. N. Elgood, resulting in the conclusion that the effective internal pressure due to wave impact cannot exceed that exerted by wave impact on the face of a breakwater, and suggesting the provision of drains opening on the sheltered face.

The section devoted to chemistry contains a critical account of a new series of methylated sugars recently obtained in the Purdie Research Laboratory at St. Andrews by Prof. Irvine. The extended application of these researches is reviewed in an excellent paper by $\mathrm{Mr}$. C. R. Young, whilst Mr. W. S. Denham ably treats of new methods in the preparation of anhydrides of organic acids, and Mr. R. C. Wallace deals with the relationships of indium and thallium. These researches give an indication of the importance and variety of the work recently carried out in this department. Under the section of natural history and medicine, Prof. McIntosh gives a brief history of the chair of natural history at St. Andrews, and Prof. D'Arcy Thompson reprints his presidential address to the British Association, entitled "Magnalia Naturæ : or the Greater Problems of Biology.' The next paper is by Prof. E. E. Prince, dealing with the pioneer work in scientific fishery investigations at St. Andrews, and makes mention of many workers, now scattered in diverse regions, who have extended our knowledge of the department in a noteworthy manner, and by none more than the writer of the article. The last is a medical contribution on the important subject of the toxicity of local anæsthetics, by Prof. C. S. Marshall, who carried out a series of careful experiments with no fewer than eight drugs.

No zoological researches are included in the volume, since its scope was not understood until too late for the insertion of the able contributions of such well-known investigators as Dr. H. C. Williamson, Dr. H. M. Kyle, Dr. Wm. Nicoll, and many others whose names appear in the list of publications emanating from the Gatty Marine Laboratory.

\section{THE CONTROL OF INSECT PESTS IN} $C A N A D A$.

$\mathrm{A}^{\mathrm{T}}$ the meeting of the Manchester Literary and PhiloA sophical Society on January 9, Dr. C. Gordon Hewitt, Dominion entomologist, gave an account of the ravages of insect pests in Canada, and the means taken by the Dominion Government to combat them. The annual opening up of vast tracts of country, previously wild, destroys the balance of nature, and swarms of insects, finding fresh stores available, devastate the new growths. Some of these insects are of native origin, but are more frequently introduced. Thus the Hessian fly, Mayetiola destructor, Say, appeared in 1816 ; the wheat midge, Diplosis tritici, Kirby, in 1828 ; the chinch bug, Blissus leucopterus, Say, in 1866 ; and the Colorado potato-beetle, Leptinotarsa decemlineata, Say, in 1870. The larch sawfly, Lygaconematus erichsonii, Hartig, reached Canada in 1882 , and in a few years destroyed the mature larches over practically the whole of eastern Canada. The pear-leaf blister-mite, Eriophyes pyri, Nalepa, was first reported from Nova Scotia about 1887, and has since spread across Canada from the Atlantic to the Pacific.

Other pests referred to included the clover-root borer, Hylesinus trifolii, Müller; the warble-fly; the apple fruitminer, Argyresthia conjugella, Z.; the apple maggot, Rhagoletis pomonella, Walsh; and the San José scale, Aspidiotus perniciosus, Comst. It was found necessary to pass the San José Scale Act, prohibiting the importation of trees and nursery stock from countries in which the scale was known to exist; in Igor the restriction was removed, but infected plants were fumigated by prussic acid before admission. The brown-tail moth, Euproctis chrysorrhoea, L., has now reached Canada, and is attacking oak, elm, and maple, in addition to fruit trees. Contrary to expectations, the severe winters of Canada do not prove to be so fatal to the larvæ; experience has shown that some 30 per cent. survive after being frozen for two months in a block of ice. Attention is therefore being given to the parasites of this species; also the severely infested trees are sprayed to kill the young larvæ.

Dr. Hewitt gave an account of the precautionary measures taken and of legislation in the Dominion, and of the history of the Entomological Department there. Educational work is undertaken, and agriculturists and associations addressed on the means of prevention and control of outbreaks. At Ontario Agricultural College, and in other provinces, men are trained to act as assistants and inspectors in this branch.

\section{EXTERNAL" DEGREES AT THE UNIVERSITY OF LONDON.}

SIR WILliaM RAMSAY'S letter to Nature on the value of the "external" degrees of the University of London, published on February I (vol. 1xxxviii., p. 445), has given rise to a number of letters upon the subject. As several correspondents traverse the same ground, and limitations of space will not permit us to publish the letters in full, we subjoin a summary of the chief points raised.

Dr. A. D. Waller, F.R.S., thinks that no useful purpose would be served by any discussion of the particular case cited by Sir William Ramsay, where it is suggested an injustice has been done to a late student of University College, and proceeds to consider the principle involved. $\mathrm{He}$ urges that the great desideratum as regards the superior degrees of the University- " internal " as well as "external" -is not the abolition of the "external" degree, but publicity during examination of both kinds. A candidate presenting a doctoral thesis to the University is, says Dr. Waller, in the position of an investigator presenting a communication to a learned society, and ought to be called upon, or permitted, to expound and uphold his thesis by speech and by demonstration in the presence of the University. The "external " examinations ought not, he maintains, to be abolished, for they have been, and are, of far-reaching value as affording a guide to study and a standard of excellence throughout the Empire.

Prof. T. Johnson, of the Royal College of Science, Dublin, directs attention to the fact that the University of London was founded, in part, for students whom circumstances prevent from attendance at the London courses of instruction, and argues against the abolition of the " external", side in the University. He contends that the agitation for the conversion of the examining into a teachin university had its origin largely in the unpublished desire to safeguard certain vested interests. It was no uncommon thing in the old days, he says, for a professor in a London college to find his salary reduced owing to loss of fees caused by his replacement, at the end of his term of office as an examiner, by a provincial or other examiner. "This "anomaly" or 'injustice' was removed by the creation of the University's teaching side and intern examinerships."

Mr. W. J. Oakes, of the Oakes Institute, Walton, Liverpool, emphasises the similarity in the requirements, so far as the arts courses are concerned, for "internal" and "external" degrees, and attaches great importance to the fact that "external" candidates for science degrees must provide suitably attested evidence of practical training in a laboratory. He points out the comparatively small provision in provincial centres of scholarships to enable young men and women to attend day courses at local universities. He asks, "What are the young men who come from homes where the income is less than 20ol. a year to do?" If no other case could be made out for the "external" degree than that of the young men who cannot possibly attend the day classes of a university, this would, $\mathrm{Mr}$. Oakes says, outweigh all the arguments which can be advanced against it. 